\title{
都市への太陽光発電システム導入に関する研究 FEASIBILITY STUDY OF INTRODUCING PHOTOVOLTAIC POWER GENERATION SYSTEMS IN CITIES
}

\author{
森圭太郎* 井村秀文 $* *$ \\ Keitaro MORI * and Hidefumi IMURA **
}

\begin{abstract}
Solar energy is clean and inexhaustible. Its use would reduce the environmental loads such as the emission of air pollutants from fossil fuels. However, commercialization of solar energy is still at its infant stage due to various technological and economical reasons. For promoting the effective utilization of solar energy systems, studies are necessary on the costs covering their installation, operation and maintenance as well as on their environmental impacts. By using a logistic model, this study presents an estimation of the solar energy generation cost when photovoltaic systems are introduced. Environmental impacts of the systems are also discussed by assuming some model cities. The results showed that the solar power generation cost using photovoltaic systems is four times as high as that of the commercial electricity. Purchasing of PV systems by public housing authorities, however, would promote their dissemination and lower their prices. If PV systems are effectively used in combination with various non-used refuse heat and natural energy sources, they could supply $35 \%$ of the total energy demand in model cities. Surface temperature of the areas would drop by $1^{\circ} \mathrm{C}$ if the PV panels are set up on two thirds of the built-up area.
\end{abstract}

KEYWORDS; solar energy, photovoltaic power generation system, eco-city, ecopolis, urban environment

\section{1.はじめに}

我が国のエネルギー消費は，化石然料を主とした供給によって支えられているが，近年，地球温暖化等の環 境問題が人類にとっての重大な問題となるにつれ，エネルギー多消費に対する具体的な対策がますます強く求 められている。太陽エネルギーはクリーンで量が膨大であることから, 代替エネルギー源として大いに期待さ れている。しかし，エネルギー密度が低く，天候に左右される等の理由により，その利用はいまだ十分に進ん でいない。太陽エネルギーの積極的な利用によって環境負荷の低隇を実現するには，その導入に対する障害を 把握し, 克服手段を明らかにする必要がある。その第一ステップとして, 導入のコストと効果を定量的に把握 することが重要である。

本研究では, 太陽光発電システムを都市に導入しょうとする場合の方法とその問題点及びその導入が都市の 環境改善にどのような効果をもたらすかを検討する。

\section{2. 太陽光発電システムの発電コスト}

太陽光発電は近年の研究開発により技術的には実用可能な状況となっている。しかし，その発電コストは現 在の電気料金に比べると高く,このことが都市への太陽光発電システム導入に対する最大の障害であると言わ れている。そこで, 逆潮流（自家発電で作った電気を配電線を通して電力会社側へ流すこと）有り, 売電（逆 潮流した電力を電力会社が買い取ること）有りの太陽光発電システムによる発電コストについて評価する。

* J R 東日本 JR East Japan

** 九州大学工学部環境システム工学研究センター Inst. of Environmental Systems, Faculty of Eng., Kyusyu University 
太陽光発電による発電コストGは以下の式で求めた。

$$
\begin{aligned}
& \mathrm{G}=\mathrm{TC} / \mathrm{TP} \\
& \mathrm{TC}=\mathrm{Cp}+\mathrm{Cb}+\mathrm{Cm} \\
& \mathrm{TP}=\mathrm{t} I \eta\{1-0.005(\mathrm{~T}-298)\}
\end{aligned}
$$

太陽光発電システムの発電コストGは，発電に必要な総経費TCを太陽電池が寿命までに発電する総発電量 TPで割った值とする。発電に必要な総経費TCは, 太陽電池バネル費 $\mathrm{Cp}$ と周辺機器（インバー夕，保護装置， 架台等）費 $\mathrm{Cb}$ 及び維持費 $\mathrm{Cm}$ の総和とする。総発電量TPは太陽電池の寿命年数に日射量と太陽光発電システ ムの発電効率及び太陽バネル温度による発電能力低下率を掛けたものとする。太陽バネル温度による発電能 力の低下は, バネル温 (円M)

度が $25^{\circ}$ Cを超えると， $1^{\circ} \mathrm{C}$ にさ $0.5 \%$ 発電能 力が低下するものとす る。

太陽電池パネル製造 ト コストの過去のトレン ドに関する習熟曲線

（図 1）によれば，太 陽電池累積生産量が 2

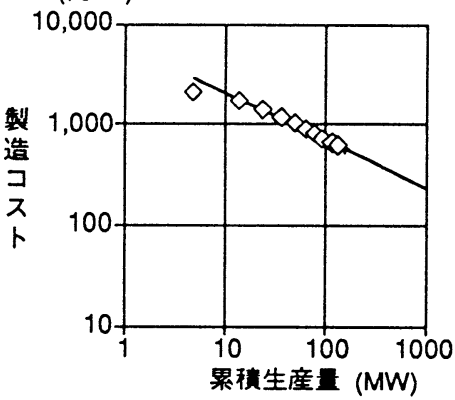

図1太陽電池パネルの習熟曲線
(千円/台)

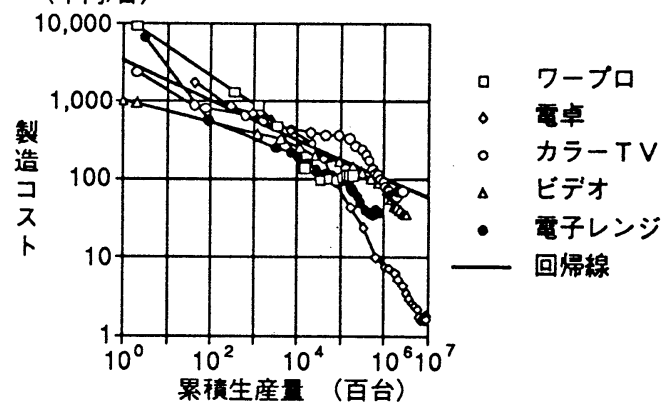

図 2 家電製品の習熟曲線

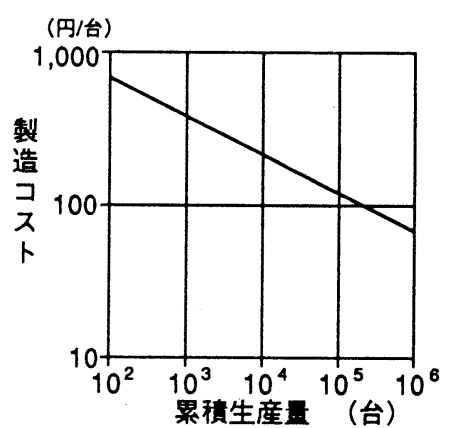

図3 周辺機器の習熟曲線

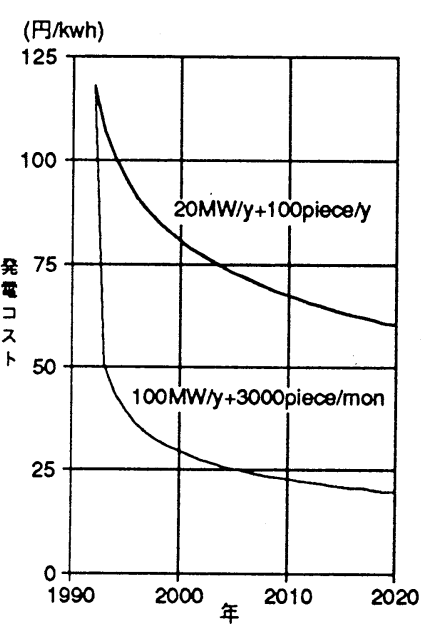

困 4 発電コストの推移 


\section{1 施策の設定}

普及促進のための施策として以下の7つを想定した。

施策1 発電に必要な総経費の $2 / 3$ を補助金で負担する。

施策2 - $\mathrm{a}$ 毎年公共新築住宅の $10 \%$ に太陽光発電システムを設置する。

施策2-b 毎年公共新築住宅の $50 \%$ に太陽光発電システムを設置する。

施策2-c 毎年公共新築住宅の $100 \%$ に太陽光発電システムを設置する。

施策3-a 年間20MWの太陽電池を輸出する。

施策3-b 年間 $40 \mathrm{MW}$ の太陽電池を輸出する。

施策 $\mathrm{A}$ 施策1と施策2を行う。

公共新築住宅の年間戸数は現在約 7 万戸であるが，ここではそのうちの一戸建て 3 万戸を対象とする。太

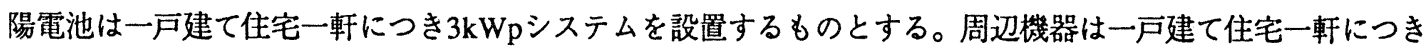
1 台必要であるとする。また，現状で毎年生産されている太陽電池量 $(20 \mathrm{MW})$ は，施策に関係なく生産さ れているものとする。

\section{2 施策後の発電コス卜推移}

発電コストの評価手法は前章に準じて行った。各施策の発電コストを困 5 に示す。その結果， イ）いずれの施策も発電コストは低下しているが 口）新築住宅への設置はその効果が大きい。すなわち，施策2-aで $40 \%$, 施策2-bで56\%，施策2-cで64\%発電コストを低下させる。八）太陽電池 の輸出による効果は小さい。これは, 太陽電池バネルの輸出は周辺機器の 需要を喚起しないためである。周辺機器累積生産量の増加による周辺機器 製造コストの低下が，発電コスト低下に大きな影響を与えている。二）補 助金での負担も発電コスト低下には有効な手段である。

3. 3 ロジスティックモデル

新しい製品や技術が市場に浸透してゆく様子はロジスティック曲線によ り説明されることが多い。ロジスティック曲線は, 市場占有率を $\mathrm{f}(\mathrm{t})$ とす ると

$$
\mathrm{f}(\mathrm{t})=\frac{1}{1+\mathrm{e}^{-\alpha \mathrm{t}-\beta}} \quad \mathrm{t}: \text { 時間, } \alpha, \beta: \text { 定数 }
$$

であるが,ここで

$\mathrm{t}_{1}$ : 市場占有率が $0.1 \%$ に達する年, $\mathrm{t}_{2}$ : 市場占有率が $50 \%$ に達する

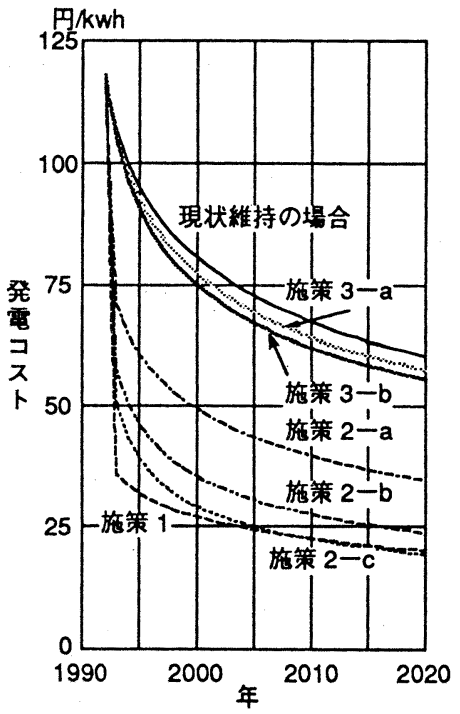

図 5 施策別発電コストの推移

年, $\mathrm{T}=\mathrm{t}_{1}-\mathrm{t}_{2}:$ 市場占有率が 0.1

\%から $50 \%$ になるまでの時間。

これをテイクオーバータイムと 呼占。

とするとロジスティック曲線 $\mathrm{f}(\mathrm{t})$ は

$f(t)=\frac{1}{1+\exp \left\{-\frac{6.90675}{T}\left(t-t_{1}-T\right)\right\}}$

で表せる。太陽光発電の普及過程は このロジスティック曲線 $\mathrm{f}(\mathrm{t})$ を用いて 計算した。計算方法は, 太陽光発電 が最大限導入され得る量, テーク
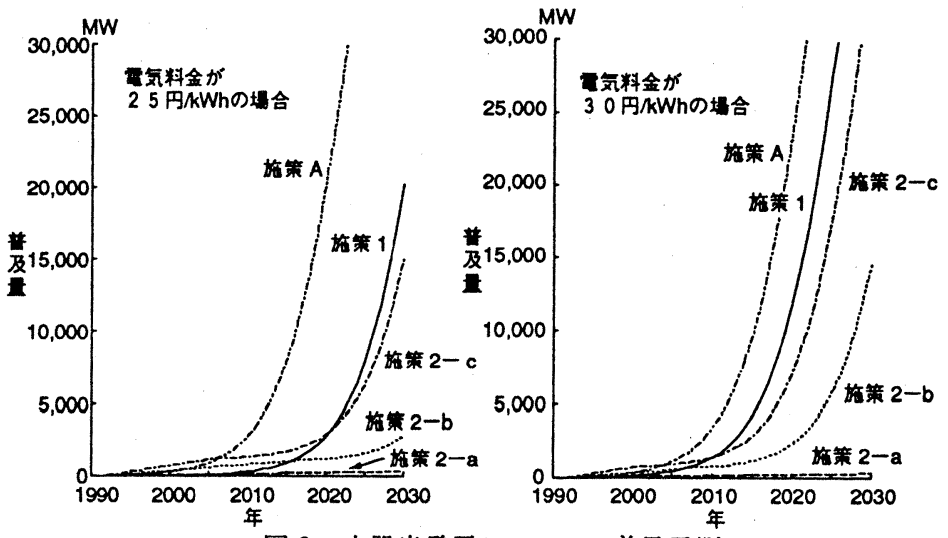

図 6 太陽光発電システムの普及予测 
オーバータイムを設定し, 各年ごと $\mathrm{f}(\mathrm{t})$ の繰り返し計算を行う。この時, 太陽光発電システムの普及開始時期 を設定し, 普及開始時期として市場占有率 $0.1 \%$ 与える。算出された市場占有率と最大導入可能量の積で, その年 $\mathrm{t}$ における太陽光発電の導入量を求める。以下 $\mathrm{t}$ に関する繰り返し計算を行う。

\section{4 施策後の普及過程推移}

太陽光発電システムの普及開始時期は，(太陽光発電システムによる発電コストミ電気料金）が成り立つ時 とし，このときの太陽光発電システムの市場占有率を $0.1 \%$ とした。テイクオーバータイムは 30 年, 太陽光発 電システムの最大導入可能量は, 71,000MWとした。

電気料金が25円/kWh と30円/kWhの場合の普及過程を施策 3-a，bを除く各施策について計算した（図6）。 施策1から施策2-cまでは，5円の電気料金上昇により普及開始時期が5７年早まっている。電気料金の上昇が 太陽光発電システムの早期普及に大きな影響を与えることがわかる。

\section{4. モデル都市への太陽光発電システム導入の効果}

太陽光発電システムを都市へ導入しょうとする場合，その導入効果を定量的 に把握することは重要である。そこで，仮想的なモデル都市を想定し，そこに 太陽光発電システムを導入した場合の効果について評価した。モデル都市は住 宅都市と業務都市を仮定し, 各都市内のエネルギー需要及び電力需要を既存の エネルギー原単位を基に求めた。また都市内に存在する未利用エネルギー（太 陽熱, コミ焼却熱, 下水廃熱）についてもその供給可能量を推定した。加え て, 太陽電池を設置したビルの地表面温度を一次元熱収支モデルで求め, 才 フィスビル街の地表面温度を考察した。

\section{1 設定条件}

モデル都市として住宅都市と業務都市を仮定した。住宅都市は人口 15,000 人 のベッドタウンを，業務都市は人口 1,100 人で 5 階建てオフィスビルが建ち並ぶ オフィス街を仮定した。都市規模を表1に示す。モデル都市の年間エネルギー 需要量は既存の原単位，2)を用いて求めた。さらに，冷・暖房用エネルギーは月 別にデグリデーに応じて配分した。給湯用エネルギーは，夏季需要量の 2 倍を冬季 需要量とした。照明動力，その他用エネルギーは毎月一定であるとした。都市内の 未利用エネルギーは，太陽熱・ゴミ焼却熱・下水廃熱を考えた。

1) 太陽熱エネルギーは太陽熱温水器を利用して全て給湯用途で利用する。利用可 能エネルギー量は, 次式で算定した。

$$
\begin{array}{ll}
\mathrm{E}_{\mathrm{h}}=\mathrm{I} \times 365 \times \eta_{\mathrm{h}} \times \mathrm{S} & \mathrm{E}_{\mathrm{h}} \text { : 利用可能太陽熱エネルギー, I : 全天日射量, } \\
& \eta_{\mathrm{h}} \text { : 熱効率, } \mathrm{S}: \text { 太陽熱温水器設置面積 }
\end{array}
$$

2) ゴミ焼却熱エネルギーは熱供給システム として冷房用 (夏季)，暖房用 (冬季)，給 湯用（それ以外）に利用する。利用可能エネ ルギー量は，以下の式で算定した。

$$
\begin{aligned}
& \mathrm{E}_{\mathrm{w}}=\mathrm{V}_{\mathrm{w}} \times 365 \times 10^{3} \times \mathrm{H} \times \alpha \times \beta \\
& \mathrm{E}_{\mathrm{wh}}=\mathrm{V}_{\mathrm{w}} \times \eta_{1} \times \eta_{\mathrm{m}} \times \mathrm{T}
\end{aligned}
$$

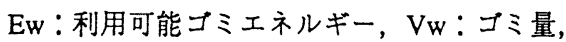

\begin{tabular}{|c|c|c|}
\hline & 太陽電池 & 太陽整温水器 \\
\hline 二戸住宅 & $30 \mathrm{~m}^{2} /$ 世带 & $2 \mathrm{~m}^{2} /$ 世带 \\
\hline 集合住宅 & $200 \mathrm{~m}^{2} /$ 棟 & $100 \mathrm{~m}^{2} /$ 棟 \\
\hline 学校 & $2,000 \mathrm{~m}^{2} /$ 校 & $100 \mathrm{~m}^{2} /$ 校 \\
\hline オフィスヒル & 幄根面積の $2 / 3$ & 屋根面積の1/4 \\
\hline 住宅都市 (ha) & 太陆笔池 & 太场哭温水器 \\
\hline 一戸住宅 & 8.1 & 0.54 \\
\hline 集合住宅 & 0.6 (30棟) & 0.3 (30棟) \\
\hline 学校 & $0.8(4$ 校 $)$ & $0.04(4$ 校 \\
\hline オフィスヒル & 0 & 0 \\
\hline 業忽都市 (ha) & 太陽笔池 & 太陽憖温水器 \\
\hline 一戸住宅 & 0 & 0 \\
\hline 集合住宅 & $0.12(6$ 棟) & 0.06 (6棟) \\
\hline 学校 & 0.2 (1校) & 0.01 (1校) \\
\hline オフィスビル & 34.2 & 12.8 \\
\hline
\end{tabular}
$\mathrm{H}$ : 発熱量, $\alpha$ : 所内利用率, $\beta$ : ボイラー効率, Ewh：利用可能コミ熱エネルギー量,

\begin{tabular}{|c|c|c|}
\hline & 住宅都市 & 業誘都市 \\
\hline 位置 & 東京周辺 & 東京周辺 \\
\hline 人口（万人） & 1.5 & 6.4(睅) \\
\hline コミ量(t/日) & 20 & 150 \\
\hline 下水量 $\left(\mathrm{m}^{3} /\right.$ 日 $)$ & 3,750 & 16,000 \\
\hline \multicolumn{3}{|l|}{ 世帯数 } \\
\hline 一可住宅 & 2,700 & $\overline{0}$ \\
\hline 集合住宅 & 1,900 & 340 \\
\hline \multicolumn{3}{|l|}{ 敷地面皘(ha) } \\
\hline 一戸住宅地 & 115 & 0 \\
\hline 藮合住宅地 & 20 & 4 \\
\hline オフィス街 & 0 & 85.5 \\
\hline 公園 & 16 & 16 \\
\hline その他 & 9 & 54.5 \\
\hline 計 & 160 & 160 \\
\hline \multicolumn{3}{|l|}{ 床面積 $\left(\mathrm{m}^{2}\right)$} \\
\hline オフィス & 0 & $1,282,500$ \\
\hline 学校 & 16,000 & 4,000 \\
\hline 飲食業 & 3,000 & 138,000 \\
\hline 小売菜 & 9,000 & 12,000 \\
\hline 病院 & 9,000 & 20,000 \\
\hline その他 & 15,000 & 20,000 \\
\hline
\end{tabular}
$\eta_{1}$ : 输送口ス, $\eta_{\mathrm{m}}$ : 機器効率, $\mathrm{T}$ : 利用期間

3）下水廃熱エネルギーはヒートポンプを利

\begin{tabular}{|c|c|}
\hline 記号 & 単位 \\
\hline $\mathrm{Vw}$ & $\begin{array}{l}20 \text { (住宅都市) } \\
150 \text { (莱柊都市) }\end{array}$ \\
\hline Vs & $\begin{array}{l}3,750 \text { (任穵都市) } \mathrm{m}^{3} / \text { 日 } \\
16,000 \text { (業磉都市) }\end{array}$ \\
\hline $\mathrm{T}$ & $\begin{array}{l}\text { ～9月(窝房) } \\
11 \sim 4 \text { (暖房) }\end{array}$ \\
\hline H & $2000 \quad \mathrm{kcal} / \mathrm{kg}$ \\
\hline$\alpha$ & 15 \\
\hline$\beta$ & 80 \\
\hline$\eta 1$ & 0.9 \\
\hline$\eta \mathrm{m}$ & \\
\hline$\eta \mathrm{e}$ & 15 \\
\hline$\eta \mathrm{c}$ & $\mathrm{kcal} / \mathrm{kwh}$ \\
\hline Ew & kcal/年 \\
\hline Ewh & $\mathrm{kcal} /$ 年 \\
\hline Ewe & $\mathrm{kcal} /$ 年 \\
\hline$\Delta t$ & ${ }^{\circ} \mathrm{C}$ \\
\hline $\mathrm{Cp}$ & $\mathrm{kcal} / \mathrm{kg} / \mathrm{C}$ \\
\hline$y$ & $\mathrm{~kg} / \mathrm{m}^{3}$ \\
\hline COP & 4 (暖房) \\
\hline Es & $\mathrm{kcal} / \mathrm{\theta}$ \\
\hline Esh & kcal/年 \\
\hline I & $\mathrm{kcal} / \mathrm{m}^{2} / \mathrm{G}$ \\
\hline$\eta \mathrm{h}$ & 30 \\
\hline 5 & $\mathrm{~m}^{2}$ \\
\hline Eh & $\mathrm{kcal} / 4$ 年 \\
\hline
\end{tabular}

表 1 都市規模

表 3 設定値 
用して冷房 (夏季) 及び暖房用 (冬季) に利用する。利用可能エネルギー量, は以下の式で算定した。

$$
\begin{array}{lll}
\mathrm{E}_{\mathrm{s}}=\mathrm{V}_{\mathrm{s}} \times \Delta \mathrm{T} \times \mathrm{C}_{\mathrm{p}} \times \gamma & & \mathrm{Es} \text { : 利用可能下水廃熟エネルギー, Vs: 下水流量, } \\
\mathrm{E}_{\mathrm{sh}}=\mathrm{E}_{\mathrm{s}} \times \frac{\mathrm{COP}}{\mathrm{COP}+1} \times \mathrm{T} & \text { (冷房時) } & \Delta \mathrm{t}: \text { 利用可能温度差, } \mathrm{Cp}: \text { 比熱, } \gamma: \text { 比重, } \\
\mathrm{E}_{\mathrm{sh}}=\mathrm{E}_{\mathrm{s}} \times \frac{\mathrm{COP}}{\mathrm{COP}-1} \times \mathrm{T} & \text { (暖房時) } & \mathrm{Esh}: \text { 利用可能冷暖房用熱エネルギ, } \\
& \mathrm{COP}: \text { 成績係数, } \mathrm{T}: \text { 利用期間 }
\end{array}
$$

さらに，モデル都市内の建築物は断熱構造とし，その断熱効果は従来の建築物に比べて冷・暖房に必要なエ ネルギーの3割が削減できるとした。太陽電池と太陽熱温水器の設置面積及び導入量を表 2 に, 設定值を表 3 に示す。

\section{2 モデル都市のエネルギー需要に関する結果}

モデル都市のエネルギー需要に関する結果を図 7，8に示す。まず，住宅都市について 次のことがいえる。1）冬季に消費される暖房用エネルギーが大きい。2）太陽光発電，未 利用エネルギーの利用, 建築物の断熱構造が都市内で全て実行された場合, エネルギー需 要は夏期で約 40\%, 冬季で約30\%の削減効果がある。一方, 業務都市では，1）冷房・暖房 用に消費されるエネルギー量がともに大きい。2）太陽光発電，未利用エネルギーの利 用, 建築物の断熱構造 $1,000 \mathrm{Mcal}$ が都市内で全て実行さ 8,00 れた場合，夏季で約 6,000 . $40 \%$ ，冬季で約 $35 \%$ の 4,000 . 削隇効果がある。

\section{3 モデル都市の供} 給エネルギーに関する 結果

図 7 によると,下水 $1,000 \mathrm{Mcal}$ 廃熱以外の未利用工ネ ルギー供給量は毎月ほ ほ安定している。ま た，太陽光発電からの エネルギー供給量も月 による変動は小さい。 4. 4 モデル都市の電 力需要に関する結果

図 9 に示すように両都市と も夏季の冷房用電力需要が大 きい。図10には未利用エネル ギー供給後の電力需要につい て示すが, 住宅都市では, 未 利用エネルギーの利用と太陽

\begin{tabular}{|c|}
\hline 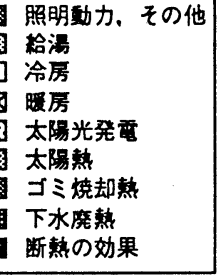 \\
\hline
\end{tabular}
光発電が行われた場合, 低温 熱源に利用される電力需要は なくなる。業務都市では，未 利用エネルギーの利用と太陽 光発電が行われた場合, 低温
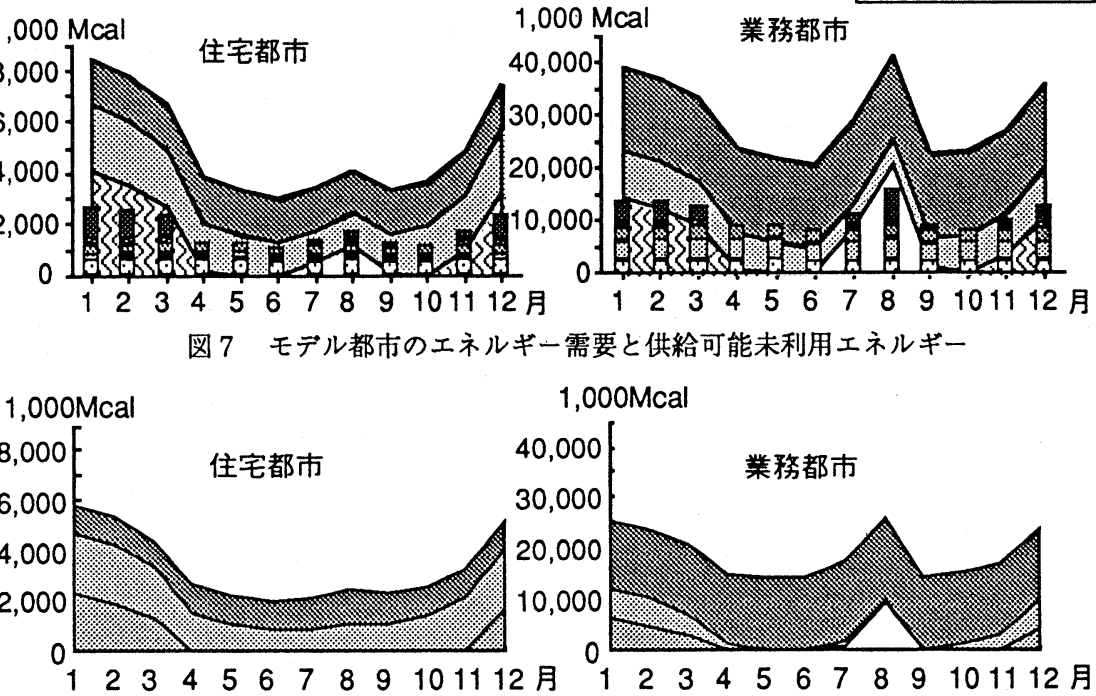

図 7 モデル都市のエネルギー需要と供給可能未利用エネルギー

\section{$1,000 \mathrm{Mcal}$}

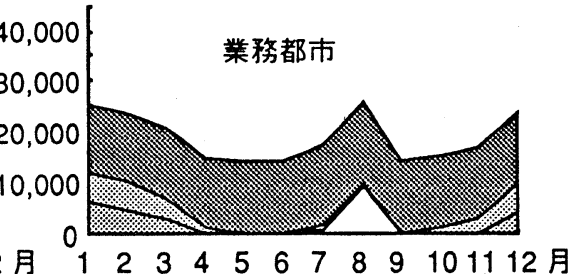

図 8 太陽光, 未利用エネルギー供給後のエネルギー需要
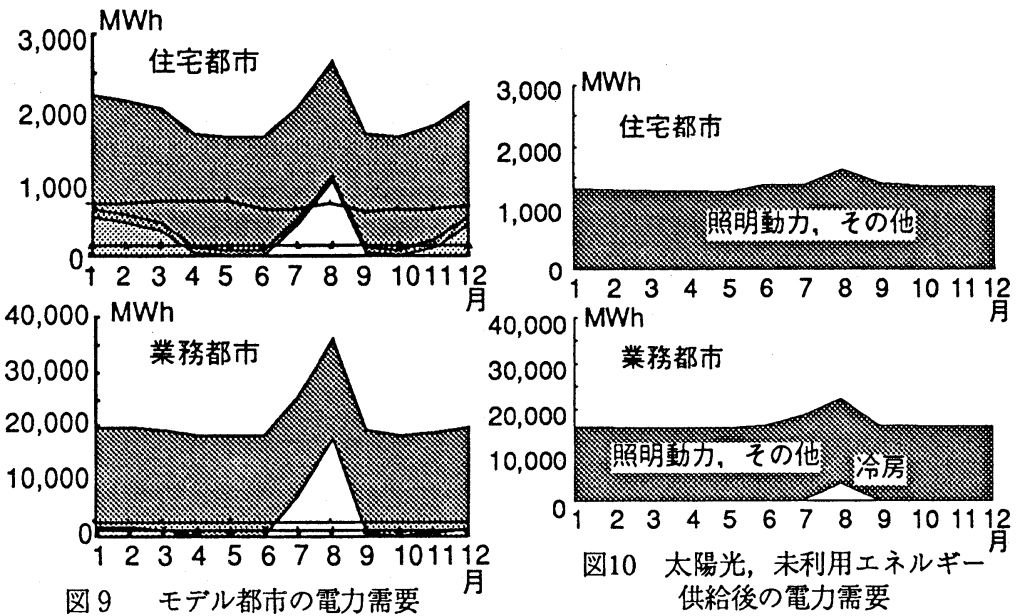
熱源用の電力需要は冷房用がわずかにあるのみである。また, いずれの都市にお いても電力の季節間格差が是正される。

\section{5 太陽電池が地表面温度に与える影響}

太陽電池は日射エネルギーの一部を電力エネルギーに変換するため, 太陽電池

表 4 敷地面皘と設置面積

を設置した構造物が吸収する日射量は減りその地表面温度は低くなる。業務都市内 表 5

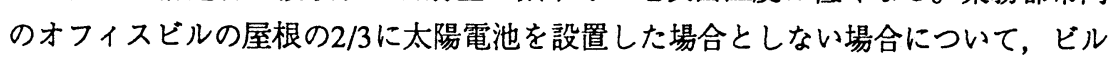
の地表面温度を一次元熱收支式》で求めた。この時, 太陽電池によって電力に変換さ れたエネルギーは地表面で反射したものとして考え，アルベド值を変化させた。季 節は8月，太陽電池の発電効率は $10 \%$ とし，表 4 に示す設置面積及び表 5 のビルにつ

\begin{tabular}{|c|c|c|}
\hline 業務都市 & $\begin{array}{l}\text { 太榎電池 } \\
\text { 設道面積 }\end{array}$ & 数地面積 \\
\hline オフィス街 & $34.2 \mathrm{ha}$ & $85.5 \mathrm{ha}$ \\
\hline
\end{tabular}
いてのバラメータを用いた。太陽電池を設置した場合のアル

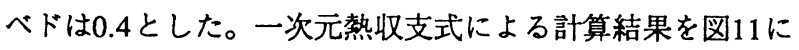
示す。この図より，ビルの地表面温度は太陽電池を設置する と昼間で約 2 C 低くなる。また, オフィス街の太陽電池設置 面積はオフイス街のビル敷地面積に対して 4 割（表 1〜3） を占めることから，業務都市のオフィスビルの屋根の $2 / 3 に$ 太陽電池を設置した場合，オフイスビル街の地表面温度の最 高温度は $1{ }^{\circ}$ C程度低下すると予測される。

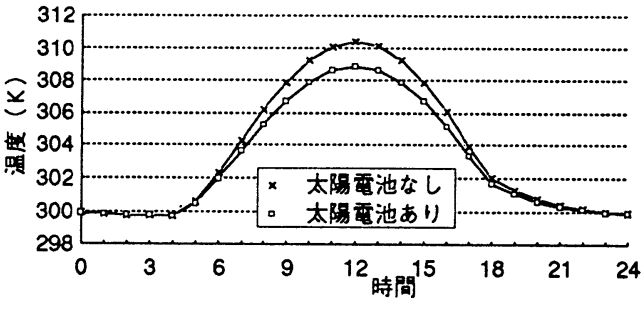

図11 ビルの地表面温度

\section{5. まとめ}

本研究では，最初に，都市への太陽光発電システム導入に際して，現在最も大きな障害となっている発電コ ストに焦点をしはり，太陽光発電システムによる発電コストの評価を行った。次に，太陽光発電システムの早 期普及のための対策を検討し数種の施策を想定した後，その施策が実施された場合の発電コストの推移と普及 過程をロジスティックモデルを用いて評価した。続いて，モデル都市として住宅都市と業務都市を仮定し，各 都市内のエネルギー需要及び電力需要を既存のエネルギー原単位を基に求めた。また，モデル都市に太陽光発 電システムを導入した場合の発電可能電力量を求め, 都市内に存在する未利用エネルギー(太陽熱, コミ焼却 熱，下水廃熱にこついてもその供給可能量を推定した。そして最後に，太陽電池を設置したビルの地表面温度 を一次元熱収支モデルで求め，モデル都市内のオフィスビル街の地表面温度を考察した。得られた結果を要約 すると以下のとおりになる。

（1）太陽光発電システムの発電コストは既存の電気料金より 4 倍以上高い。太陽電池が年間 $100 \mathrm{MW}$ ，周辺 機器が月間3,000台で生産された場合は，2005年頃には既存の電気料金と競合できるようになる。

（2）太陽光発電システムの新築住宅への設置や補助金の交付は発電コストを大きく下げる。新篡住宅の $10 \%$ に設置した場合では40\%，50\%に設置した場合で56\%，100\%に設置した場合で64\%発電コストを低下させる。 また，電気料金を 5 円上昇した場合，普及開始時期は 5 7年早まる。

（3）モデル都市内の太陽光発電，未利用エネルギーの利用，建築物の断熱構造化が全て実行された場合，既 存システムからのエネルギー需要量は平均 $35 \%$ 削減できる。特に低温熱源用の電力需要が減りエネルギーの有 効利用が可能である。

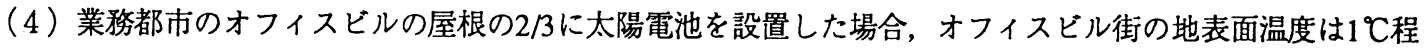
度低下する。

\section{参考文献}

1）住環境計画研究所：昭和63年版家庭用エネルギー統計年報, 1989

2）日本エネルギー経済研究所：昭和63年度業務用エネルギー消費実態調查

3）上野賢仁他：環境システム, Vol.20, pp 262 269, 1992 
オーバータイムを設定し, 各年ごと $\mathrm{f}(\mathrm{t})$ の繰り返し計算を行う。この時, 太陽光発電システムの普及開始時期 を設定し, 普及開始時期として市場占有率 $0.1 \%$ 与える。算出された市場占有率と最大導入可能量の積で, その年 $\mathrm{t}$ における太陽光発電の導入量を求める。以下 $\mathrm{t}$ に関する繰り返し計算を行う。

\section{4 施策後の普及過程推移}

太陽光発電システムの普及開始時期は，(太陽光発電システムによる発電コストミ電気料金）が成り立つ時 とし，このときの太陽光発電システムの市場占有率を $0.1 \%$ とした。テイクオーバータイムは 30 年, 太陽光発 電システムの最大導入可能量は, 71,000MWとした。

電気料金が25円/kWh と30円/kWhの場合の普及過程を施策 3-a，bを除く各施策について計算した（図6）。 施策1から施策2-cまでは，5円の電気料金上昇により普及開始時期が5７年早まっている。電気料金の上昇が 太陽光発電システムの早期普及に大きな影響を与えることがわかる。

\section{4. モデル都市への太陽光発電システム導入の効果}

太陽光発電システムを都市へ導入しょうとする場合，その導入効果を定量的 に把握することは重要である。そこで，仮想的なモデル都市を想定し，そこに 太陽光発電システムを導入した場合の効果について評価した。モデル都市は住 宅都市と業務都市を仮定し, 各都市内のエネルギー需要及び電力需要を既存の エネルギー原単位を基に求めた。また都市内に存在する未利用エネルギー（太 陽熱, コミ焼却熱, 下水廃熱）についてもその供給可能量を推定した。加え て, 太陽電池を設置したビルの地表面温度を一次元熱収支モデルで求め, 才 フィスビル街の地表面温度を考察した。

\section{1 設定条件}

モデル都市として住宅都市と業務都市を仮定した。住宅都市は人口 15,000 人 のベッドタウンを，業務都市は人口 1,100 人で 5 階建てオフィスビルが建ち並ぶ オフィス街を仮定した。都市規模を表1に示す。モデル都市の年間エネルギー 需要量は既存の原単位，2)を用いて求めた。さらに，冷・暖房用エネルギーは月 別にデグリデーに応じて配分した。給湯用エネルギーは，夏季需要量の 2 倍を冬季 需要量とした。照明動力，その他用エネルギーは毎月一定であるとした。都市内の 未利用エネルギーは，太陽熱・ゴミ焼却熱・下水廃熱を考えた。

1) 太陽熱エネルギーは太陽熱温水器を利用して全て給湯用途で利用する。利用可 能エネルギー量は, 次式で算定した。

$$
\begin{array}{ll}
\mathrm{E}_{\mathrm{h}}=\mathrm{I} \times 365 \times \eta_{\mathrm{h}} \times \mathrm{S} & \mathrm{E}_{\mathrm{h}} \text { : 利用可能太陽熱エネルギー, I : 全天日射量, } \\
& \eta_{\mathrm{h}} \text { : 熱効率, } \mathrm{S}: \text { 太陽熱温水器設置面積 }
\end{array}
$$

2) ゴミ焼却熱エネルギーは熱供給システム として冷房用 (夏季)，暖房用 (冬季)，給 湯用（それ以外）に利用する。利用可能エネ ルギー量は，以下の式で算定した。

$$
\begin{aligned}
& \mathrm{E}_{\mathrm{w}}=\mathrm{V}_{\mathrm{w}} \times 365 \times 10^{3} \times \mathrm{H} \times \alpha \times \beta \\
& \mathrm{E}_{\mathrm{wh}}=\mathrm{V}_{\mathrm{w}} \times \eta_{1} \times \eta_{\mathrm{m}} \times \mathrm{T}
\end{aligned}
$$

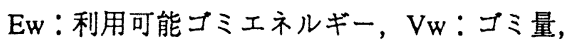

\begin{tabular}{|c|c|c|}
\hline & 太陽電池 & 太陽整温水器 \\
\hline 二戸住宅 & $30 \mathrm{~m}^{2} /$ 世带 & $2 \mathrm{~m}^{2} /$ 世带 \\
\hline 集合住宅 & $200 \mathrm{~m}^{2} /$ 棟 & $100 \mathrm{~m}^{2} /$ 棟 \\
\hline 学校 & $2,000 \mathrm{~m}^{2} /$ 校 & $100 \mathrm{~m}^{2} /$ 校 \\
\hline オフィスヒル & 幄根面積の $2 / 3$ & 屋根面積の1/4 \\
\hline 住宅都市 (ha) & 太陆笔池 & 太场哭温水器 \\
\hline 一戸住宅 & 8.1 & 0.54 \\
\hline 集合住宅 & 0.6 (30棟) & 0.3 (30棟) \\
\hline 学校 & $0.8(4$ 校 $)$ & $0.04(4$ 校 \\
\hline オフィスヒル & 0 & 0 \\
\hline 業忽都市 (ha) & 太陽笔池 & 太陽憖温水器 \\
\hline 一戸住宅 & 0 & 0 \\
\hline 集合住宅 & $0.12(6$ 棟) & 0.06 (6棟) \\
\hline 学校 & 0.2 (1校) & 0.01 (1校) \\
\hline オフィスビル & 34.2 & 12.8 \\
\hline
\end{tabular}
$\mathrm{H}$ : 発熱量, $\alpha$ : 所内利用率, $\beta$ : ボイラー効率, Ewh：利用可能コミ熱エネルギー量,

\begin{tabular}{|c|c|c|}
\hline & 住宅都市 & 業誘都市 \\
\hline 位置 & 東京周辺 & 東京周辺 \\
\hline 人口（万人） & 1.5 & 6.4(睅) \\
\hline コミ量(t/日) & 20 & 150 \\
\hline 下水量 $\left(\mathrm{m}^{3} /\right.$ 日 $)$ & 3,750 & 16,000 \\
\hline \multicolumn{3}{|l|}{ 世帯数 } \\
\hline 一可住宅 & 2,700 & $\overline{0}$ \\
\hline 集合住宅 & 1,900 & 340 \\
\hline \multicolumn{3}{|l|}{ 敷地面皘(ha) } \\
\hline 一戸住宅地 & 115 & 0 \\
\hline 藮合住宅地 & 20 & 4 \\
\hline オフィス街 & 0 & 85.5 \\
\hline 公園 & 16 & 16 \\
\hline その他 & 9 & 54.5 \\
\hline 計 & 160 & 160 \\
\hline \multicolumn{3}{|l|}{ 床面積 $\left(\mathrm{m}^{2}\right)$} \\
\hline オフィス & 0 & $1,282,500$ \\
\hline 学校 & 16,000 & 4,000 \\
\hline 飲食業 & 3,000 & 138,000 \\
\hline 小売菜 & 9,000 & 12,000 \\
\hline 病院 & 9,000 & 20,000 \\
\hline その他 & 15,000 & 20,000 \\
\hline
\end{tabular}
$\eta_{1}$ : 输送口ス, $\eta_{\mathrm{m}}$ : 機器効率, $\mathrm{T}$ : 利用期間

3）下水廃熱エネルギーはヒートポンプを利

\begin{tabular}{|c|c|}
\hline 記号 & 単位 \\
\hline $\mathrm{Vw}$ & $\begin{array}{l}20 \text { (住宅都市) } \\
150 \text { (莱柊都市) }\end{array}$ \\
\hline Vs & $\begin{array}{l}3,750 \text { (任穵都市) } \mathrm{m}^{3} / \text { 日 } \\
16,000 \text { (業磉都市) }\end{array}$ \\
\hline $\mathrm{T}$ & $\begin{array}{l}\text { ～9月(窝房) } \\
11 \sim 4 \text { (暖房) }\end{array}$ \\
\hline H & $2000 \quad \mathrm{kcal} / \mathrm{kg}$ \\
\hline$\alpha$ & 15 \\
\hline$\beta$ & 80 \\
\hline$\eta 1$ & 0.9 \\
\hline$\eta \mathrm{m}$ & \\
\hline$\eta \mathrm{e}$ & 15 \\
\hline$\eta \mathrm{c}$ & $\mathrm{kcal} / \mathrm{kwh}$ \\
\hline Ew & kcal/年 \\
\hline Ewh & $\mathrm{kcal} /$ 年 \\
\hline Ewe & $\mathrm{kcal} /$ 年 \\
\hline$\Delta t$ & ${ }^{\circ} \mathrm{C}$ \\
\hline $\mathrm{Cp}$ & $\mathrm{kcal} / \mathrm{kg} / \mathrm{C}$ \\
\hline$y$ & $\mathrm{~kg} / \mathrm{m}^{3}$ \\
\hline COP & 4 (暖房) \\
\hline Es & $\mathrm{kcal} / \mathrm{\theta}$ \\
\hline Esh & kcal/年 \\
\hline I & $\mathrm{kcal} / \mathrm{m}^{2} / \mathrm{G}$ \\
\hline$\eta \mathrm{h}$ & 30 \\
\hline 5 & $\mathrm{~m}^{2}$ \\
\hline Eh & $\mathrm{kcal} / 4$ 年 \\
\hline
\end{tabular}

表 1 都市規模

表 3 設定値 
用して冷房 (夏季) 及び暖房用 (冬季) に利用する。利用可能エネルギー量, は以下の式で算定した。

$$
\begin{array}{lll}
\mathrm{E}_{\mathrm{s}}=\mathrm{V}_{\mathrm{s}} \times \Delta \mathrm{T} \times \mathrm{C}_{\mathrm{p}} \times \gamma & & \mathrm{Es} \text { : 利用可能下水廃熟エネルギー, Vs: 下水流量, } \\
\mathrm{E}_{\mathrm{sh}}=\mathrm{E}_{\mathrm{s}} \times \frac{\mathrm{COP}}{\mathrm{COP}+1} \times \mathrm{T} & \text { (冷房時) } & \Delta \mathrm{t}: \text { 利用可能温度差, } \mathrm{Cp}: \text { 比熱, } \gamma: \text { 比重, } \\
\mathrm{E}_{\mathrm{sh}}=\mathrm{E}_{\mathrm{s}} \times \frac{\mathrm{COP}}{\mathrm{COP}-1} \times \mathrm{T} & \text { (暖房時) } & \mathrm{Esh}: \text { 利用可能冷暖房用熱エネルギ, } \\
& \mathrm{COP}: \text { 成績係数, } \mathrm{T}: \text { 利用期間 }
\end{array}
$$

さらに，モデル都市内の建築物は断熱構造とし，その断熱効果は従来の建築物に比べて冷・暖房に必要なエ ネルギーの3割が削減できるとした。太陽電池と太陽熱温水器の設置面積及び導入量を表 2 に, 設定值を表 3 に示す。

\section{2 モデル都市のエネルギー需要に関する結果}

モデル都市のエネルギー需要に関する結果を図 7，8に示す。まず，住宅都市について 次のことがいえる。1）冬季に消費される暖房用エネルギーが大きい。2）太陽光発電，未 利用エネルギーの利用, 建築物の断熱構造が都市内で全て実行された場合, エネルギー需 要は夏期で約 40\%, 冬季で約30\%の削減効果がある。一方, 業務都市では，1）冷房・暖房 用に消費されるエネルギー量がともに大きい。2）太陽光発電，未利用エネルギーの利 用, 建築物の断熱構造 $1,000 \mathrm{Mcal}$ が都市内で全て実行さ 8,00 れた場合，夏季で約 6,000 . $40 \%$ ，冬季で約 $35 \%$ の 4,000 . 削隇効果がある。

\section{3 モデル都市の供} 給エネルギーに関する 結果

図 7 によると,下水 $1,000 \mathrm{Mcal}$ 廃熱以外の未利用工ネ ルギー供給量は毎月ほ ほ安定している。ま た，太陽光発電からの エネルギー供給量も月 による変動は小さい。 4. 4 モデル都市の電 力需要に関する結果

図 9 に示すように両都市と も夏季の冷房用電力需要が大 きい。図10には未利用エネル ギー供給後の電力需要につい て示すが, 住宅都市では, 未 利用エネルギーの利用と太陽

\begin{tabular}{|c|}
\hline 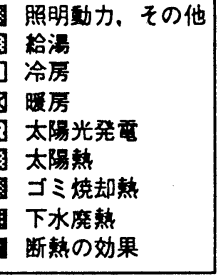 \\
\hline
\end{tabular}
光発電が行われた場合, 低温 熱源に利用される電力需要は なくなる。業務都市では，未 利用エネルギーの利用と太陽 光発電が行われた場合, 低温
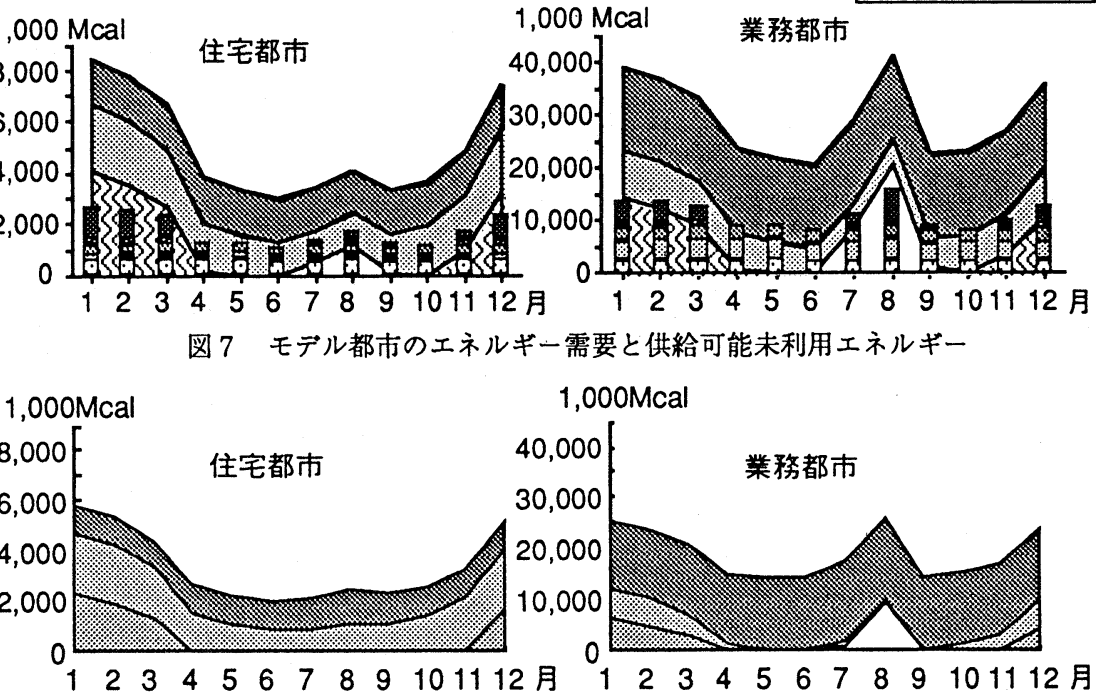

図 7 モデル都市のエネルギー需要と供給可能未利用エネルギー

\section{$1,000 \mathrm{Mcal}$}

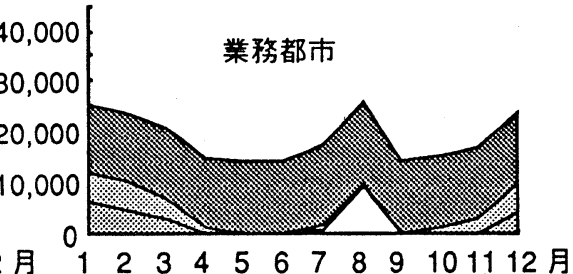

図 8 太陽光, 未利用エネルギー供給後のエネルギー需要
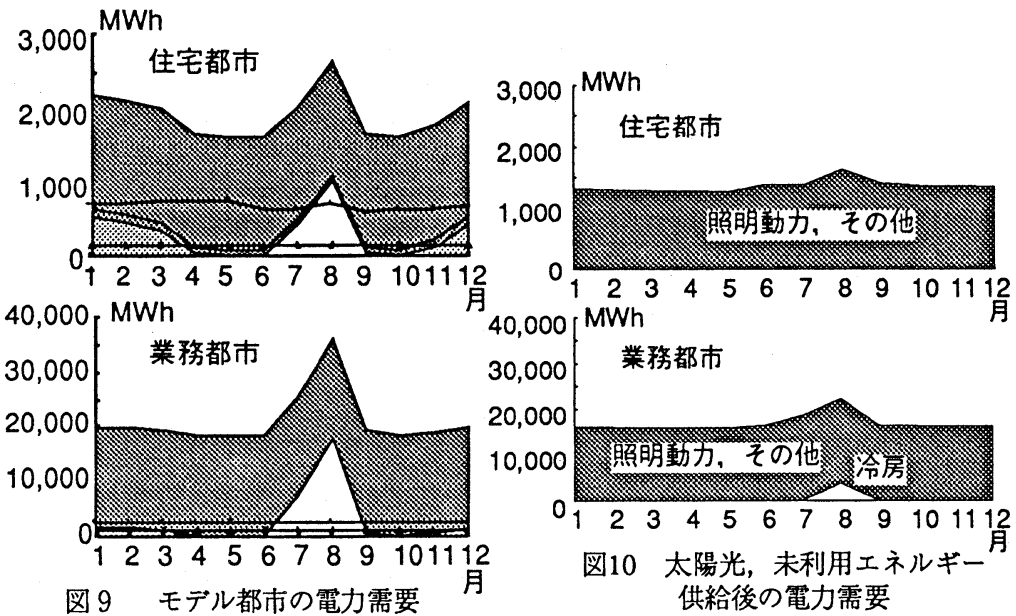
熱源用の電力需要は冷房用がわずかにあるのみである。また, いずれの都市にお いても電力の季節間格差が是正される。

\section{5 太陽電池が地表面温度に与える影響}

太陽電池は日射エネルギーの一部を電力エネルギーに変換するため, 太陽電池

表 4 敷地面皘と設置面積

を設置した構造物が吸収する日射量は減りその地表面温度は低くなる。業務都市内 表 5

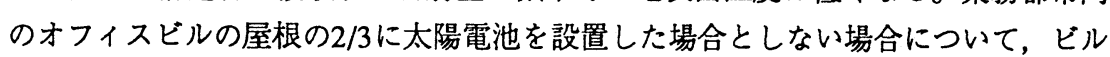
の地表面温度を一次元熱收支式》で求めた。この時, 太陽電池によって電力に変換さ れたエネルギーは地表面で反射したものとして考え，アルベド值を変化させた。季 節は8月，太陽電池の発電効率は $10 \%$ とし，表 4 に示す設置面積及び表 5 のビルにつ

\begin{tabular}{|c|c|c|}
\hline 業務都市 & $\begin{array}{l}\text { 太榎電池 } \\
\text { 設道面積 }\end{array}$ & 数地面積 \\
\hline オフィス街 & $34.2 \mathrm{ha}$ & $85.5 \mathrm{ha}$ \\
\hline
\end{tabular}
いてのバラメータを用いた。太陽電池を設置した場合のアル

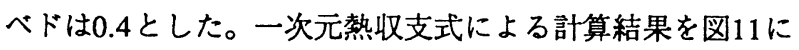
示す。この図より，ビルの地表面温度は太陽電池を設置する と昼間で約 2 C 低くなる。また, オフィス街の太陽電池設置 面積はオフイス街のビル敷地面積に対して 4 割（表 1〜3） を占めることから，業務都市のオフィスビルの屋根の $2 / 3 に$ 太陽電池を設置した場合，オフイスビル街の地表面温度の最 高温度は $1{ }^{\circ}$ C程度低下すると予測される。

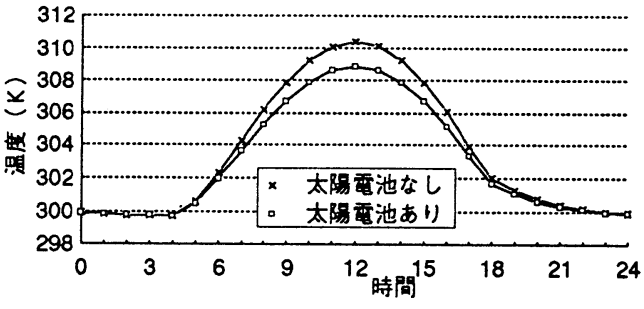

図11 ビルの地表面温度

\section{5. まとめ}

本研究では，最初に，都市への太陽光発電システム導入に際して，現在最も大きな障害となっている発電コ ストに焦点をしはり，太陽光発電システムによる発電コストの評価を行った。次に，太陽光発電システムの早 期普及のための対策を検討し数種の施策を想定した後，その施策が実施された場合の発電コストの推移と普及 過程をロジスティックモデルを用いて評価した。続いて，モデル都市として住宅都市と業務都市を仮定し，各 都市内のエネルギー需要及び電力需要を既存のエネルギー原単位を基に求めた。また，モデル都市に太陽光発 電システムを導入した場合の発電可能電力量を求め, 都市内に存在する未利用エネルギー(太陽熱, コミ焼却 熱，下水廃熱にこついてもその供給可能量を推定した。そして最後に，太陽電池を設置したビルの地表面温度 を一次元熱収支モデルで求め，モデル都市内のオフィスビル街の地表面温度を考察した。得られた結果を要約 すると以下のとおりになる。

（1）太陽光発電システムの発電コストは既存の電気料金より 4 倍以上高い。太陽電池が年間 $100 \mathrm{MW}$ ，周辺 機器が月間3,000台で生産された場合は，2005年頃には既存の電気料金と競合できるようになる。

（2）太陽光発電システムの新築住宅への設置や補助金の交付は発電コストを大きく下げる。新篡住宅の $10 \%$ に設置した場合では40\%，50\%に設置した場合で56\%，100\%に設置した場合で64\%発電コストを低下させる。 また，電気料金を 5 円上昇した場合，普及開始時期は 5 7年早まる。

（3）モデル都市内の太陽光発電，未利用エネルギーの利用，建築物の断熱構造化が全て実行された場合，既 存システムからのエネルギー需要量は平均 $35 \%$ 削減できる。特に低温熱源用の電力需要が減りエネルギーの有 効利用が可能である。

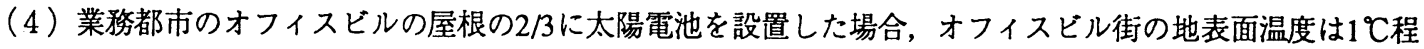
度低下する。

\section{参考文献}

1）住環境計画研究所：昭和63年版家庭用エネルギー統計年報, 1989

2）日本エネルギー経済研究所：昭和63年度業務用エネルギー消費実態調查

3）上野賢仁他：環境システム, Vol.20, pp 262 269, 1992 
オーバータイムを設定し, 各年ごと $\mathrm{f}(\mathrm{t})$ の繰り返し計算を行う。この時, 太陽光発電システムの普及開始時期 を設定し, 普及開始時期として市場占有率 $0.1 \%$ 与える。算出された市場占有率と最大導入可能量の積で, その年 $\mathrm{t}$ における太陽光発電の導入量を求める。以下 $\mathrm{t}$ に関する繰り返し計算を行う。

\section{4 施策後の普及過程推移}

太陽光発電システムの普及開始時期は，(太陽光発電システムによる発電コストミ電気料金）が成り立つ時 とし，このときの太陽光発電システムの市場占有率を $0.1 \%$ とした。テイクオーバータイムは 30 年, 太陽光発 電システムの最大導入可能量は, 71,000MWとした。

電気料金が25円/kWh と30円/kWhの場合の普及過程を施策 3-a，bを除く各施策について計算した（図6）。 施策1から施策2-cまでは，5円の電気料金上昇により普及開始時期が5７年早まっている。電気料金の上昇が 太陽光発電システムの早期普及に大きな影響を与えることがわかる。

\section{4. モデル都市への太陽光発電システム導入の効果}

太陽光発電システムを都市へ導入しょうとする場合，その導入効果を定量的 に把握することは重要である。そこで，仮想的なモデル都市を想定し，そこに 太陽光発電システムを導入した場合の効果について評価した。モデル都市は住 宅都市と業務都市を仮定し, 各都市内のエネルギー需要及び電力需要を既存の エネルギー原単位を基に求めた。また都市内に存在する未利用エネルギー（太 陽熱, コミ焼却熱, 下水廃熱）についてもその供給可能量を推定した。加え て, 太陽電池を設置したビルの地表面温度を一次元熱収支モデルで求め, 才 フィスビル街の地表面温度を考察した。

\section{1 設定条件}

モデル都市として住宅都市と業務都市を仮定した。住宅都市は人口 15,000 人 のベッドタウンを，業務都市は人口 1,100 人で 5 階建てオフィスビルが建ち並ぶ オフィス街を仮定した。都市規模を表1に示す。モデル都市の年間エネルギー 需要量は既存の原単位，2)を用いて求めた。さらに，冷・暖房用エネルギーは月 別にデグリデーに応じて配分した。給湯用エネルギーは，夏季需要量の 2 倍を冬季 需要量とした。照明動力，その他用エネルギーは毎月一定であるとした。都市内の 未利用エネルギーは，太陽熱・ゴミ焼却熱・下水廃熱を考えた。

1) 太陽熱エネルギーは太陽熱温水器を利用して全て給湯用途で利用する。利用可 能エネルギー量は, 次式で算定した。

$$
\begin{array}{ll}
\mathrm{E}_{\mathrm{h}}=\mathrm{I} \times 365 \times \eta_{\mathrm{h}} \times \mathrm{S} & \mathrm{E}_{\mathrm{h}} \text { : 利用可能太陽熱エネルギー, I : 全天日射量, } \\
& \eta_{\mathrm{h}} \text { : 熱効率, } \mathrm{S}: \text { 太陽熱温水器設置面積 }
\end{array}
$$

2) ゴミ焼却熱エネルギーは熱供給システム として冷房用 (夏季)，暖房用 (冬季)，給 湯用（それ以外）に利用する。利用可能エネ ルギー量は，以下の式で算定した。

$$
\begin{aligned}
& \mathrm{E}_{\mathrm{w}}=\mathrm{V}_{\mathrm{w}} \times 365 \times 10^{3} \times \mathrm{H} \times \alpha \times \beta \\
& \mathrm{E}_{\mathrm{wh}}=\mathrm{V}_{\mathrm{w}} \times \eta_{1} \times \eta_{\mathrm{m}} \times \mathrm{T}
\end{aligned}
$$

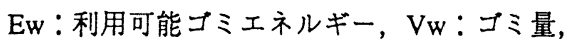

\begin{tabular}{|c|c|c|}
\hline & 太陽電池 & 太陽整温水器 \\
\hline 二戸住宅 & $30 \mathrm{~m}^{2} /$ 世带 & $2 \mathrm{~m}^{2} /$ 世带 \\
\hline 集合住宅 & $200 \mathrm{~m}^{2} /$ 棟 & $100 \mathrm{~m}^{2} /$ 棟 \\
\hline 学校 & $2,000 \mathrm{~m}^{2} /$ 校 & $100 \mathrm{~m}^{2} /$ 校 \\
\hline オフィスヒル & 幄根面積の $2 / 3$ & 屋根面積の1/4 \\
\hline 住宅都市 (ha) & 太陆笔池 & 太场哭温水器 \\
\hline 一戸住宅 & 8.1 & 0.54 \\
\hline 集合住宅 & 0.6 (30棟) & 0.3 (30棟) \\
\hline 学校 & $0.8(4$ 校 $)$ & $0.04(4$ 校 \\
\hline オフィスヒル & 0 & 0 \\
\hline 業忽都市 (ha) & 太陽笔池 & 太陽憖温水器 \\
\hline 一戸住宅 & 0 & 0 \\
\hline 集合住宅 & $0.12(6$ 棟) & 0.06 (6棟) \\
\hline 学校 & 0.2 (1校) & 0.01 (1校) \\
\hline オフィスビル & 34.2 & 12.8 \\
\hline
\end{tabular}
$\mathrm{H}$ : 発熱量, $\alpha$ : 所内利用率, $\beta$ : ボイラー効率, Ewh：利用可能コミ熱エネルギー量,

\begin{tabular}{|c|c|c|}
\hline & 住宅都市 & 業誘都市 \\
\hline 位置 & 東京周辺 & 東京周辺 \\
\hline 人口（万人） & 1.5 & 6.4(睅) \\
\hline コミ量(t/日) & 20 & 150 \\
\hline 下水量 $\left(\mathrm{m}^{3} /\right.$ 日 $)$ & 3,750 & 16,000 \\
\hline \multicolumn{3}{|l|}{ 世帯数 } \\
\hline 一可住宅 & 2,700 & $\overline{0}$ \\
\hline 集合住宅 & 1,900 & 340 \\
\hline \multicolumn{3}{|l|}{ 敷地面皘(ha) } \\
\hline 一戸住宅地 & 115 & 0 \\
\hline 藮合住宅地 & 20 & 4 \\
\hline オフィス街 & 0 & 85.5 \\
\hline 公園 & 16 & 16 \\
\hline その他 & 9 & 54.5 \\
\hline 計 & 160 & 160 \\
\hline \multicolumn{3}{|l|}{ 床面積 $\left(\mathrm{m}^{2}\right)$} \\
\hline オフィス & 0 & $1,282,500$ \\
\hline 学校 & 16,000 & 4,000 \\
\hline 飲食業 & 3,000 & 138,000 \\
\hline 小売菜 & 9,000 & 12,000 \\
\hline 病院 & 9,000 & 20,000 \\
\hline その他 & 15,000 & 20,000 \\
\hline
\end{tabular}
$\eta_{1}$ : 输送口ス, $\eta_{\mathrm{m}}$ : 機器効率, $\mathrm{T}$ : 利用期間

3）下水廃熱エネルギーはヒートポンプを利

\begin{tabular}{|c|c|}
\hline 記号 & 単位 \\
\hline $\mathrm{Vw}$ & $\begin{array}{l}20 \text { (住宅都市) } \\
150 \text { (莱柊都市) }\end{array}$ \\
\hline Vs & $\begin{array}{l}3,750 \text { (任穵都市) } \mathrm{m}^{3} / \text { 日 } \\
16,000 \text { (業磉都市) }\end{array}$ \\
\hline $\mathrm{T}$ & $\begin{array}{l}\text { ～9月(窝房) } \\
11 \sim 4 \text { (暖房) }\end{array}$ \\
\hline H & $2000 \quad \mathrm{kcal} / \mathrm{kg}$ \\
\hline$\alpha$ & 15 \\
\hline$\beta$ & 80 \\
\hline$\eta 1$ & 0.9 \\
\hline$\eta \mathrm{m}$ & \\
\hline$\eta \mathrm{e}$ & 15 \\
\hline$\eta \mathrm{c}$ & $\mathrm{kcal} / \mathrm{kwh}$ \\
\hline Ew & kcal/年 \\
\hline Ewh & $\mathrm{kcal} /$ 年 \\
\hline Ewe & $\mathrm{kcal} /$ 年 \\
\hline$\Delta t$ & ${ }^{\circ} \mathrm{C}$ \\
\hline $\mathrm{Cp}$ & $\mathrm{kcal} / \mathrm{kg} / \mathrm{C}$ \\
\hline$y$ & $\mathrm{~kg} / \mathrm{m}^{3}$ \\
\hline COP & 4 (暖房) \\
\hline Es & $\mathrm{kcal} / \mathrm{\theta}$ \\
\hline Esh & kcal/年 \\
\hline I & $\mathrm{kcal} / \mathrm{m}^{2} / \mathrm{G}$ \\
\hline$\eta \mathrm{h}$ & 30 \\
\hline 5 & $\mathrm{~m}^{2}$ \\
\hline Eh & $\mathrm{kcal} / 4$ 年 \\
\hline
\end{tabular}

表 1 都市規模

表 3 設定値 
用して冷房 (夏季) 及び暖房用 (冬季) に利用する。利用可能エネルギー量, は以下の式で算定した。

$$
\begin{array}{lll}
\mathrm{E}_{\mathrm{s}}=\mathrm{V}_{\mathrm{s}} \times \Delta \mathrm{T} \times \mathrm{C}_{\mathrm{p}} \times \gamma & & \mathrm{Es} \text { : 利用可能下水廃熟エネルギー, Vs: 下水流量, } \\
\mathrm{E}_{\mathrm{sh}}=\mathrm{E}_{\mathrm{s}} \times \frac{\mathrm{COP}}{\mathrm{COP}+1} \times \mathrm{T} & \text { (冷房時) } & \Delta \mathrm{t}: \text { 利用可能温度差, } \mathrm{Cp}: \text { 比熱, } \gamma: \text { 比重, } \\
\mathrm{E}_{\mathrm{sh}}=\mathrm{E}_{\mathrm{s}} \times \frac{\mathrm{COP}}{\mathrm{COP}-1} \times \mathrm{T} & \text { (暖房時) } & \mathrm{Esh}: \text { 利用可能冷暖房用熱エネルギ, } \\
& \mathrm{COP}: \text { 成績係数, } \mathrm{T}: \text { 利用期間 }
\end{array}
$$

さらに，モデル都市内の建築物は断熱構造とし，その断熱効果は従来の建築物に比べて冷・暖房に必要なエ ネルギーの3割が削減できるとした。太陽電池と太陽熱温水器の設置面積及び導入量を表 2 に, 設定值を表 3 に示す。

\section{2 モデル都市のエネルギー需要に関する結果}

モデル都市のエネルギー需要に関する結果を図 7，8に示す。まず，住宅都市について 次のことがいえる。1）冬季に消費される暖房用エネルギーが大きい。2）太陽光発電，未 利用エネルギーの利用, 建築物の断熱構造が都市内で全て実行された場合, エネルギー需 要は夏期で約 40\%, 冬季で約30\%の削減効果がある。一方, 業務都市では，1）冷房・暖房 用に消費されるエネルギー量がともに大きい。2）太陽光発電，未利用エネルギーの利 用, 建築物の断熱構造 $1,000 \mathrm{Mcal}$ が都市内で全て実行さ 8,00 れた場合，夏季で約 6,000 . $40 \%$ ，冬季で約 $35 \%$ の 4,000 . 削隇効果がある。

\section{3 モデル都市の供} 給エネルギーに関する 結果

図 7 によると,下水 $1,000 \mathrm{Mcal}$ 廃熱以外の未利用工ネ ルギー供給量は毎月ほ ほ安定している。ま た，太陽光発電からの エネルギー供給量も月 による変動は小さい。 4. 4 モデル都市の電 力需要に関する結果

図 9 に示すように両都市と も夏季の冷房用電力需要が大 きい。図10には未利用エネル ギー供給後の電力需要につい て示すが, 住宅都市では, 未 利用エネルギーの利用と太陽

\begin{tabular}{|c|}
\hline 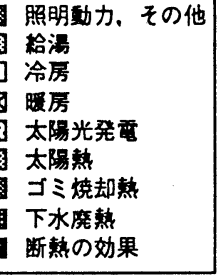 \\
\hline
\end{tabular}
光発電が行われた場合, 低温 熱源に利用される電力需要は なくなる。業務都市では，未 利用エネルギーの利用と太陽 光発電が行われた場合, 低温
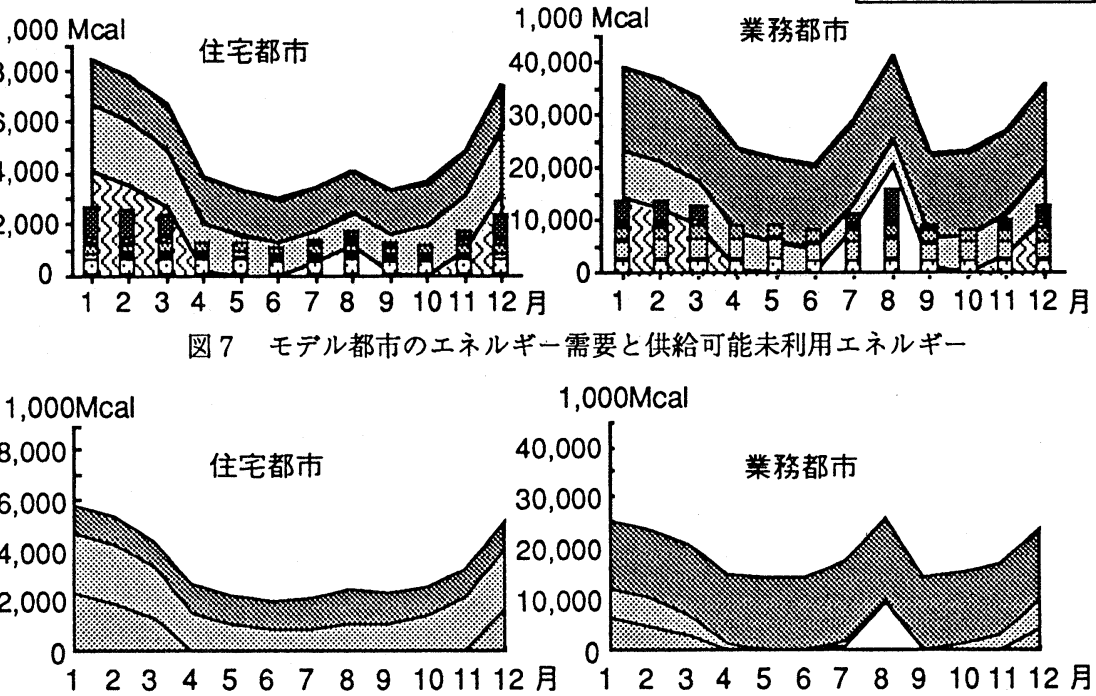

図 7 モデル都市のエネルギー需要と供給可能未利用エネルギー

\section{$1,000 \mathrm{Mcal}$}

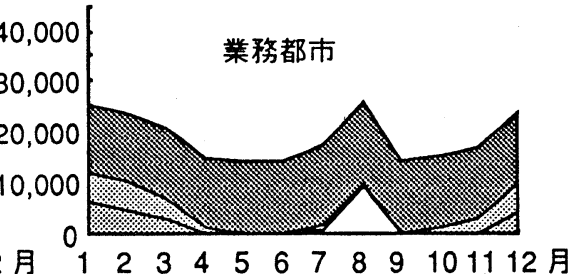

図 8 太陽光, 未利用エネルギー供給後のエネルギー需要
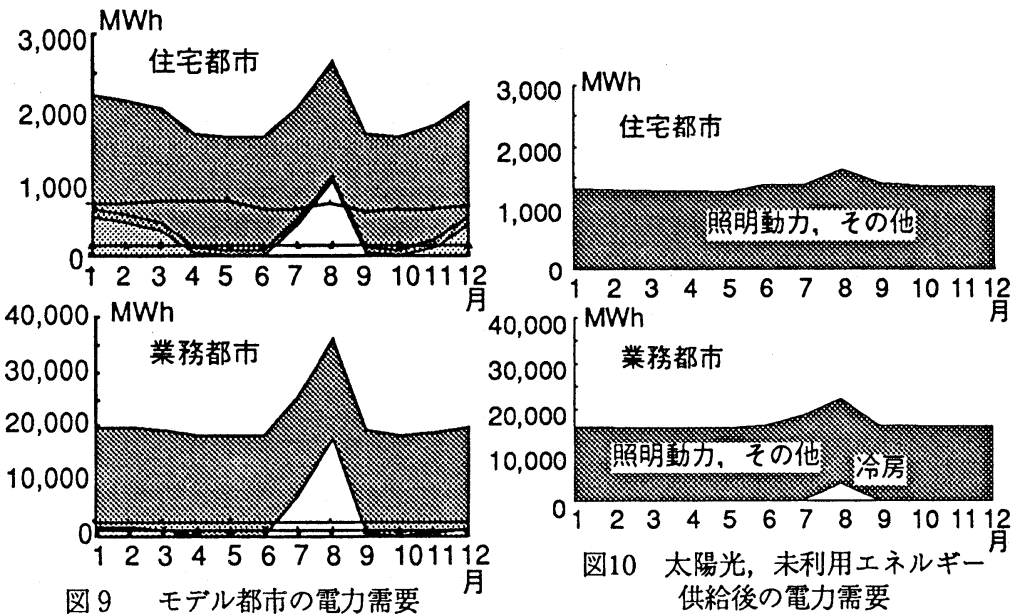
熱源用の電力需要は冷房用がわずかにあるのみである。また, いずれの都市にお いても電力の季節間格差が是正される。

\section{5 太陽電池が地表面温度に与える影響}

太陽電池は日射エネルギーの一部を電力エネルギーに変換するため, 太陽電池

表 4 敷地面皘と設置面積

を設置した構造物が吸収する日射量は減りその地表面温度は低くなる。業務都市内 表 5

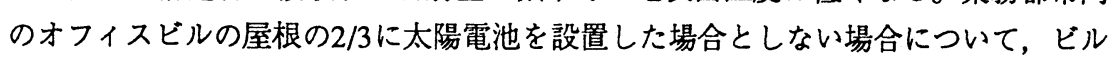
の地表面温度を一次元熱收支式》で求めた。この時, 太陽電池によって電力に変換さ れたエネルギーは地表面で反射したものとして考え，アルベド值を変化させた。季 節は8月，太陽電池の発電効率は $10 \%$ とし，表 4 に示す設置面積及び表 5 のビルにつ

\begin{tabular}{|c|c|c|}
\hline 業務都市 & $\begin{array}{l}\text { 太榎電池 } \\
\text { 設道面積 }\end{array}$ & 数地面積 \\
\hline オフィス街 & $34.2 \mathrm{ha}$ & $85.5 \mathrm{ha}$ \\
\hline
\end{tabular}
いてのバラメータを用いた。太陽電池を設置した場合のアル

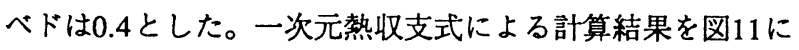
示す。この図より，ビルの地表面温度は太陽電池を設置する と昼間で約 2 C 低くなる。また, オフィス街の太陽電池設置 面積はオフイス街のビル敷地面積に対して 4 割（表 1〜3） を占めることから，業務都市のオフィスビルの屋根の $2 / 3 に$ 太陽電池を設置した場合，オフイスビル街の地表面温度の最 高温度は $1{ }^{\circ}$ C程度低下すると予測される。

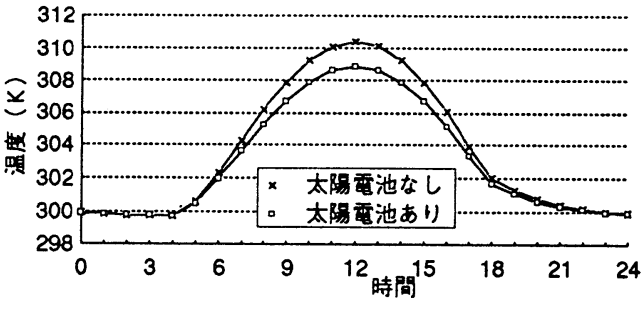

図11 ビルの地表面温度

\section{5. まとめ}

本研究では，最初に，都市への太陽光発電システム導入に際して，現在最も大きな障害となっている発電コ ストに焦点をしはり，太陽光発電システムによる発電コストの評価を行った。次に，太陽光発電システムの早 期普及のための対策を検討し数種の施策を想定した後，その施策が実施された場合の発電コストの推移と普及 過程をロジスティックモデルを用いて評価した。続いて，モデル都市として住宅都市と業務都市を仮定し，各 都市内のエネルギー需要及び電力需要を既存のエネルギー原単位を基に求めた。また，モデル都市に太陽光発 電システムを導入した場合の発電可能電力量を求め, 都市内に存在する未利用エネルギー(太陽熱, コミ焼却 熱，下水廃熱にこついてもその供給可能量を推定した。そして最後に，太陽電池を設置したビルの地表面温度 を一次元熱収支モデルで求め，モデル都市内のオフィスビル街の地表面温度を考察した。得られた結果を要約 すると以下のとおりになる。

（1）太陽光発電システムの発電コストは既存の電気料金より 4 倍以上高い。太陽電池が年間 $100 \mathrm{MW}$ ，周辺 機器が月間3,000台で生産された場合は，2005年頃には既存の電気料金と競合できるようになる。

（2）太陽光発電システムの新築住宅への設置や補助金の交付は発電コストを大きく下げる。新篡住宅の $10 \%$ に設置した場合では40\%，50\%に設置した場合で56\%，100\%に設置した場合で64\%発電コストを低下させる。 また，電気料金を 5 円上昇した場合，普及開始時期は 5 7年早まる。

（3）モデル都市内の太陽光発電，未利用エネルギーの利用，建築物の断熱構造化が全て実行された場合，既 存システムからのエネルギー需要量は平均 $35 \%$ 削減できる。特に低温熱源用の電力需要が減りエネルギーの有 効利用が可能である。

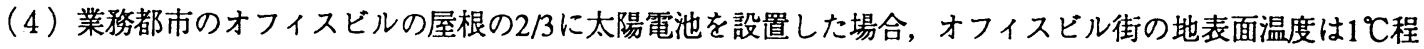
度低下する。

\section{参考文献}

1）住環境計画研究所：昭和63年版家庭用エネルギー統計年報, 1989

2）日本エネルギー経済研究所：昭和63年度業務用エネルギー消費実態調查

3）上野賢仁他：環境システム, Vol.20, pp 262 269, 1992 